\title{
METAPRAGMATICS OF ADMINISTERING JUSTICE IN RUSSIAN AND ENGLISH JUDICIAL DISCOURSE
}

\author{
Tatiana Dubrovskaya \\ Penza State University \\ 40 Krasnaya str., Penza, Russia, 440000
}

\begin{abstract}
This paper is intended as a contribution to a body of research on metapragmatics in courtroom settings, particularly in Russian and English judicial discourse, and presents the results of functional analysis of metapragmatic elements. In the article, I claim that meta-utterances are inherent in judicial discourse and perform specific functions that are essential for practising judicial power and discretion in court as well as administering justice. The paper discusses functions of meta-utterances as they are presented in recent scholarship and offers a three-group classification of metapragmatic elements in judicial discourse, according to the types of reality distinguished in (Gibbons 2003). The first group contributes to constructing the primary reality, i.e. the reality of the courtroom; the second group assists in framing the secondary reality, i.e. the reality of the crime or misdemeanor; the third group deals with framing the legal reality. Altogether, these groups of metapragmatic elements construct an organizational frame for the trial. Data for the analysis are drawn from a few trial transcripts of modern Russian and English cases (1998-2008). By using Russian and English data for the analysis, it is demonstrated that the principal functions of judicial meta-utterances are marked by parallelism in Russian and English, while minor differences discovered are related to some other pragmatic categories, e.g. politeness, that are more nationally and culturally specific.
\end{abstract}

Keywords: metapragmatics, judicial discourse, function, courtroom, Russian, English

\section{INTRODUCTION}

The White Rabbit put on his spectacles. 'Where shall I begin, please your Majesty?' he asked.

'Begin at the beginning', the King said gravely, 'and go on till you come to the end: then stop'.

L. Carrol. Alice's Adventures in Wonderland

Metadiscourse in different types of situational context has been a subject intensely explored in pragmatics. Recent papers on metadiscourse include both those focusing on theoretical aspects of the phenomenon and those considering specifics of meta-utterances in different types of discourse. Already vast and multi-faceted, the body of scholarship on metadiscourse is continuing to grow. Apparently, there are a few reasons for this. Enumerating aspects of interest and importance in the study of metadiscourse, Vande Kopple points to at least three of them: metadiscourse studies demonstrate how intricate the language structure can be and how attentive to detail one should be when doing research in language; research on metadiscourse opens up intriguing questions about ethics, including the question how fair and just (or unfair and unjust) ways of using metadiscourse can be; language studies reveal differences in using metadiscourse in similar texts in different languages (Vande Kopple 2012: 40 41). All of the aforementioned 
reasons for further development of metadiscourse studies pertain to a greater or lesser degree to judicial discourse, which is the object of analysis in this paper.

The aim of this paper does not presuppose getting involved into terminological disputes (for the discussion of differences between and approaches to metalanguage, metacommunication, metalinguistic messages, reflexive language, metadiscourse see e.g. (Hübler \& Bublitz 2007)). I only need to explain the logic of using terminology in this paper. When quoting other authors, I will use their terms. However, my terminological preference in this study is 'metapragmatics'. By the term 'metapragmatics' I refer to "the pragmatics of metacommunicative utterances in use", following Hübler \& Bublitz (2007: 1), who "investigate how interactants actually employ meta-utterances to intervene in on-going discourse". Understanding of metapragmatics as "the management of discourse" (Caffi 2006: 85) is most relevant to the aims of the present study.

Unlike abundant research in metapragmatics in some non-institutional and institutional spheres, e.g. everyday communication, academic settings, politics, newspaper discourse, etc. (Haberland 2007; Gillaerts \& Van de Velde 2010; Schubert 2012; Mur-Dueñas 2007, 2011; Suzuki 2007; Thompson 2003; Hyland 2004; Ilie 2003; Viktorova 2011; Khabbazi-Oskouei 2013), research of legal metapragmatics seems to be limited to only a few publications. Janney distinguishes metapragmatic framing strategies employed by an attorney in courtroom examination to comment on the adequacy, clarity, relevance and truthfulness of the defendant's answers (Janney 2007). Carranza concentrates on reflexive elements in closing arguments of Argentinian criminal trials and identifies the functions of metapragmatics in this courtroom genre (Carranza 2008). Andrus makes enquiry into language ideology in Anglo-American law, which understands some types of utterances to be more objective than others (Andrus 2009).

As can be seen, none of these works discusses the specifics of metapragmatics in judicial utterances. This paper is intended as a contribution to a body of research on metapragmatics in courtroom settings, particularly in the speech of judges, i.e. judicial discourse. I will illustrate that meta-utterances are inherent in judicial discourse and possess enormous pragmatic potential, performing specific functions that are essential for constructing the judge's identity, practising power in court and administering justice. Meta-utterances in judicial speech construct an organizational frame for the trial. By using Russian and English data for the analysis, it will be demonstrated that the principal functions of judicial meta-utterances are parallel in Russian and English, while minor differences discovered are related to some other pragmatic categories, e.g. politeness, that are more nationally and culturally specific.

Data for analysis are drawn from trial transcripts of a few cases: the trial against Jehovah's Witnesses (Russia, 1998-2002); David Irving v. Penguin Books \& Deborah Lipstadt (UK, 2000); Regina v. Harold Shipman (UK, 1999-2000), as well as from handwritten notes taken by the author in the process of trial observations (2008).

In Section 2 of the article I will summarise approaches to metapragmatic utterances based on their functions. Section 3 will define specific functions of metapragmatic utterances in Russian and English judicial discourse and comment on their particular linguistic realisations. Conclusions will be drawn in Section 4. 


\section{META-UTTERANCES AND THEIR FUNCTIONS}

Discussion of meta-utterances usually involves two intersecting issues: functional potential of meta-utterances and their formal characteristics. Speaking of formal features of metadiscourse, "a truly wide-ranging, disparate set of data is included under this heading" (Ifantidou 2005: 1326), and such a wide array of heterogeneous linguistic resources is at speakers' disposal that researchers face the problem of finding a unified formal criterion to define what metapragmatic acts are. Hyland \& Tse (2004: 158) point out that:

there are no simple linguistic criteria for identifying metadiscourse. Not only is it an open category to which new items can be added to fit the writer's needs, but the same items can function as metadiscourse in some parts of the text and not in others. Consequently, metadiscourse studies begin with functional classifications and analyses of texts.

Functions of metapragmatic utterances present the other side of the coin. Scholars of metadiscourse studies ascribe a number of subfunctions to metalinguistic utterances which constitute together a more general function of managing discourse and interpersonal relations between communicants.

Hyland characterises metadiscourse as "those aspects of the text which explicitly refer to the organization of the discourse or the writer's stance towards either its content or the reader" (Hyland 1998: 438). In a later work, Hyland \& Tse (2004: 158) indicate two main functions of metadiscoursal comments: textual and interpersonal. The former organises discourse, while the latter explicates the writer's attitude to the text and makes it comprehensible to the reader.

In the same vein as Hyland, the authors of another study claim: "Metadiscourse, then, focuses our attention on aspects of a text which organize the discourse, engage the audience and signal the writer's attitude" (Fuertes-Olivera et al. 2001: 1292).

Stubbs offers a wide interpretation of metacommunication (1983: 48):

Metacommunication seems to include: messages about the channels of communication, checks on whether they are open and working; messages which serve to keep communication ticking over smoothly; control over who speaks and how much, and cues for speakers to stop talking or to interrupt (e.g. cues for turn-taking); checks on whether messages have been received and understood; and control over the content of acceptable communication.

Some studies place more emphasis either on text-structuring or communicationoriented aspects of metadiscoursal elements. The former receives attention in Thompson's study of metadiscourse in academic lectures (Thompson 2003). Defining the role of metadiscourse, Thompson indicates its text-structuring function and focuses on how both "metadiscourse and intonation are used by academic speakers to help an audience form a coherent 'mental map' of the overall talk and how its parts are interconnected" (Thompson 2003: 5).

Communicative value of metapragmatics discourse is central to some other studies. Penz analyses the functions of metacommunicative comments in international project work and discovers how they are used to organise the process of group work (Penz 2007). A few functions of metacommunication are distinguished which go beyond structuring the text and are essential for social interaction: summing-up of what has been done, suggesting further directions, negotiating the process of group work. 
Analysing classroom activities, Ciliberti \& Anderson (2004: 146) also emphasise social aspects of metapragmatic discourse and argue that it "serves to establish, maintain and modify the academic, participatory, instructional and intertextual frames on which this understanding is based". Moreover, reflexive activities structure the participation and socialisation of pupils.

Thus, two principal functional aspects of metapragmatics are highlighted: textual and interactional. On the one hand, metapragmatic utterances serve to structure the body of the discourse; on the other hand, they organise, regulate and modify the situation of speech interaction.

In their attempt to summarise and systematise types of metapragmatic acts, Hübler \& Bublitz develop a taxonomy based on metapragmatic functions (Hübler \& Bublitz 2007). The taxonomy rests on a general illocutionary force defined by the authors as the function of monitoring. Hübler \& Bublitz (2007: 17) indicate: "In many cases, monitoring is certainly an important or even the central purpose. In other cases, it may be the common denominator of a wide array of more specific functions that could be explicated, where required or desired". These specific communicative functions, the scholars argue, can be lumped together into three main groups: (1) evaluative; (2) communication oriented (including interpersonal and means-related) and (3) instrumentalized (Hübler \& Bublitz 2007: 18). The last group, which — along with a subfunction of reinforcing a communicative norm - includes a subfunction of constructing identity, is particularly valuable for our study. Constructing identity through metapragmatic means is a function that is less widely explored as compared to text-structuring and interactional functions. However, in an institutional context, constructing identity is not only an integral part of communication; it is central to performing institutional duties by speakers. Judicial discourse provides an apt example of how metapragmatic utterances contribute to constructing both the identity of a judge and social institution of justice.

\section{METAPRAGMATICS OF JUDICIAL DISCOURSE}

The importance of understanding of the situational context for interpretation of metapragmatic units in discourse has already been emphasised in previous studies. Hyland claims that metadiscourse "is not an independent stylistic device which authors can vary at will. It is integral to the contexts in which it occurs and is intimately linked to the norms and expectations of particular cultural and professional communities" (Hyland 1998: 438). Paraphrasing Hyland, Fuertes-Olivera et al. (2001: 1292) note: “...To understand the pragmatics of metadiscourse we must situate it in its appropriate setting and genre".

To situate the consideration of metapragmatics in judicial discourse, there is a need to outline the specifics of courtroom settings which presuppose particular ways of using language by trial participants.

An essential characteristic of courtroom interaction is the asymmetry of statuses among its interactants. In a trial, participants with professional statuses are granted more power and freedom in their verbal activities. Although restricted by legal procedures in this or that way, professional participants take the lead and manage courtroom dis- 
course, unlike non-professional participants, who are not supposed to explicate speech initiative. This also applies to metapragmatic acts.

In principle, of course, metapragmatic acting is reciprocal and egalitarian, i.e., each participant involved is entitled to act metapragmatically at any time. However, this general principle finds its limits in the distinctive conditions of the current discourse type or interactive frame $<\ldots>$ While, e.g., in everyday conversations the right to act metapragmatically is usually symmetrically distributed between persons of equal status, other discourse types such as courtroom interrogation $<_{\ldots} . .>$ or instructional discourse $<\ldots>$ are asymmetrical in this respect, with one party being privileged. (Hübler \& Bublitz 2007: 15)

With respect to courtroom discourse, it is expedient to talk about a hierarchy of roles: at the top of this hierarchy is the judge, who controls both professionals (prosecutors, barristers) and non-professionals (witnesses, defendants, experts); at a lower level are professional lawyers, who exert control over non-professionals; at the bottom of the hierarchy are non-professional participants, who receive very limited freedom of selfexpression.

Metapragmatic units are distributed correspondingly between the participants of courtroom interaction, with the largest body of metapragmatics belonging - for an obvious reason - to the judge. The greatest freedom in terms of metapragmatic commenting in court is in the hands of judges, who play a key role in organising a trial and perform a ruling function on a metapragmatic level. The issues of courtroom control and loss of it were previously discussed by Philips who writes: "Courtroom control centrally refers to the judge's ability literally to exert command from a distance over the actions of the physical bodies of those in his courtroom without recourse to physical coercion. This command is carried out through speech and largely involves control over the speech of others" (Philips 1998: 89). The scholar enumerates several key reasons why courtroom control presents a very important issue for the judiciary. One of them is that "loss of control can destroy the legal validity of a procedure. Words can be uttered that are inconsistent with the legal reality being constructed <... " (Philips 1998: 92). In other words, improper speech contributions of trial participants can destroy the trial as a socially consistent procedure.

Secondly, courtroom discourse is a phenomenon whose complexity is predetermined not only by a large number of interactants but also by intersecting planes of reality. Gibbons (2003: 129) explains the difference between various realities and points out:

$<\ldots>$ Two intersecting planes of reality are manifested in courtroom discourse: the primary courtroom reality, consisting of the courtroom itself and the people present; and the secondary reality, the events that are the subject of the litigation $<\ldots>$ The two layers are in constant interaction.

Along with these two realities of a trial, Gibbons (2003: 129) distinguishes a third one: "A third plane that comes into play is the law itself".

I view the three intersecting realities distinguished by Gibbons as an appropriate ground for building a classification of metapragmatic units that would reflect the specifics of courtroom interaction and the judges' role in it. I claim that metapragmatic units in judicial discourse can be grouped into three types depending on the reality they are constructing or remodeling. 


\subsection{Regulating the courtroom reality}

Metapragmatic units of the first group are aimed at regulating the primary reality, i.e. the reality of courtroom, maintaining standard legal procedures and norms of behaviour. These metapragmatics comments are addressed mostly to non-professional participants, people who are not familiar with the legal sphere and need guidance on what to do in court.

The judge starts the examination with imposing particular duties on a witness ${ }^{1}$ :

(1) Судья: Теперь переходим к допросу свидетеля. Паспорт пожалуйста ваш.... Называйте правильно ваму фалилию, имя, отчество. Вы допрашиваетесь по делу в качестве свидетеля. Вы несете уголовную ответственность за дачу ложных показаний и за отказ от дачи показаний, должны говорить только правду. Подойдите, распишитесь... Скажите нам, где вы работаете? (С.И.)

[Judge: Now we are proceeding to the witness examination. Your passport, please... Give your last name, first name, patronymic. You are examined as a witness in the case. You have a legal responsibility for giving false evidence and refusing to give evidence. You must tell only truth. Come up, sign...Tell us, where do you work? (J.W.)]

The utterance, which is metapragmatic in its character, presents an obvious example of practising procedural power by a judge. The affirmative forms are examined, have transform metapragmatic instructions into statements of fact that are not subject to discussion. The modal construction must tell imposes a procedural obligation on a witness, while imperative structures come up, sign, tell provide step-by-step instructions.

At the end of the examination the judge enforces restrictions on a witness, reminding her of the necessity to keep everything in secret and not discuss the evidence with anybody:

(2) Judge: <...> Mrs. Woodruff, I am sure I don't need to tell you this but forgive me if I just remind you that whilst you are giving your evidence you must not talk about any aspect of this case or any aspect of your evidence to anybody at all unless I give you permission to do so. Only I can give permission. I am sure you understand that. (Sh.)

The judge's explicitly expressed prohibition must not talk, unless I give you permission is mitigated - to some degree - by his preceding polite remark I don't need to tell you and an apology forgive me. However, these linguistic means of politeness have a purely formal character and do not imply any freedom on the part of the witness. The judge finishes the utterance unambiguously Only I can give permission.

Judicial metapragmatic commentaries prove to be necessary when speech behaviour of trial participants appears to be inconsistent with their role in court. For instance, witnesses can only answer questions, but they are not allowed to ask them. In example (3) this rule is violated, and the judge reminds the witness of his duties:

(3) Адвокат: ...T.е. вы считаете, что приемлемо заменять зависимость от наркотиков на православную, но неприемлемо на неондуистскую, или как?

${ }^{1}$ Hereinafter, Russian examples will be accompanied by fluent English translations. Where specific grammatical forms are meaningful, I will also provide necessary comments on them. 
Свидетель: А вы как-то сталкивались с системой самого Маршака?

Адвокат: Нет, не сталкивался.

Судья: Отвечайте, отвечайте на вопрос. (С.И.)

[Barrister: So you believe that it is acceptable to substitute a dependence on drugs with the dependence on orthodox religion, but it is unacceptable to do so with neoHinduism, or what?

Witness: Have you encountered the system by Marshak?

Barrister: No, I haven't.

Judge: Answer, answer the question! (J.W.)]

The distinctive features of courtroom communication are its planned character and precise distribution of speech roles. The parties know in advance what kind of statements they are supposed to make at a particular stage of the trial. However, the judge constantly manages the trial by announcing further activities in the courtroom, and with metapragmatic fragments of considerable length the judge informs trial participants of his plans:

(4) Judge: ...There are one or two points that I think I ought to put really to both sides. I will do that whenever it is convenient to you both. I will either do it before or during or after, whichever you find convenient - probably after, I suspect. (Ir.)

In the following example the judge intends to finish the hearing and acquaints the parties with his plans, thus, forcing them to stop:

(5) Judge: ...Now I realize time is passing but it is obviously sensible to conclude everything today, and I hope I can perhaps do it in this comprehensive way. (Ir.)

Managing the primary reality also involves regulation of turn-taking. Turn-taking often occurs in the form of interruptions of other participants by the judge, who marks turn-taking either by brief apologies as in example (6),

(6) Judge: Sorry, we are talking about the Müller document, are we not? Claimant: We are talking about the Müller document. (Ir.)

or by longer metapragmatic structures which explain why the interruption is necessary as in example (7):

(7) Claimant: My Lord, to my knowledge, I have challenged... Judge: Yes. If I may intervene and say that I would find it easier if there were not such an overt reaction to what you are saying on the other side of the court. (Ir.)

Metapragmatic comments also concern the language that the participants use to convey information. In example (8) the claimant corrects the word usage in the judge's utterance, but the latter insists on his intentional lexical choice:

(8) Judge: ... What I will ask you to do though is this. If you either dispute that you ever made the concessions that the Defendants say you made, or you want now to reconsiderClaimant: Resign.

Judge: Well, I was trying not to use that word actually - to reconsider, then would you write to me and to the Defendants, shortly setting out what you say you said, or what you now say? (Ir.) 
Metapragmatic units in the judge's speech may be aimed at regulating not only speech activities performed by other trial participants but also their physical actions, e.g. leaving the court, as in examples (9) and (10):

(9) Judge: Thank you very much, Mrs. Woodruff. You are free to go and that will apply to all witnesses unless I give a specific direction to the contrary. (Sh.);

(10) Судья: У Вас нет больше вопросов к свидетелю? Все, спасибо. Вы уже можете присесть или идти домой. (С.И.)

[Judge: You don't have any other questions to the witness? That's all. Thank you. You may take a seat or go home. (J.W.)]

In both examples (9) and (10) the judges thank the witnesses, but the English instruction features formal vocabulary (will apply, specific direction, to the contrary) and sounds more official.

Apart from procedural mistakes that can be explained by a lack of procedural knowledge, witnesses also make mistakes of violating widely accepted norms of behavior in public, and judges' metapragmatic commentaries correct such misbehaviour. In Russian courts visitors often fail to switch off their mobiles, although judges give warnings at the beginning of a proceeding. Later on, during the trial the judge has to discipline the witness:

(11) Во время допроса свидетеля у него в кармане звонит телефон.

Судья: Телефон у кого-то? Чей? Отключите. (Р.3.)

[During the examination of a witness a mobile phone is ringing in his pocket. Judge: Somebody's telephone? Whose? Switch it off. (H.N.)]

The English data do not reveal similar examples, apparently because it is prohibited to bring technical devices into the English court.

In metapragmatic units judges may choose to explicitly refer to their power to prove the legitimacy of their demands, as happens in the following example:

(12) Свидетель вышел давать показания и жует жевательную резинку.

Судья: Смирнов, перестаньте жевать. Это общественное место. И это - суд, одна из ветвей власти. Представьте, что перед Вами президент Российской Федерации. Вы же не будете перед ним жевать. Суд тоже власть. Чтоб не проглотить, выплюньте. (Р.3.)

[A witness is about to give evidence and is chewing gum.

Judge: Smirnov, stop chewing. This is a public place. And it is the Court - one of the branches of power. Imagine there is the President of the Russian Federation in front of you. You would not chew in front of him, would you? The Court is power, too. If you don't want to swallow it, spit it out. (H.N.)]

The judge points twice to the misbehaviour (chew), two times accentuates that the court is a power institution and gives two instructions formulated as imperatives (stop, spit out).

Thus, metapragmatic units in judicial speech that belong to the first type and are employed to build the reality of the courtroom are mostly regulative. Their linguistic forms transpire through means of deontic modality, which embrace imperatives, modal verbs as well as affirmative statements. 


\subsection{Constructing the reality of the crime}

Metapragmatic units of the second group are aimed at creating the secondary reality, the reality of the crime or misdemeanor and other events outside the courtroom which are being reconstructed in witnesses' and defendants' evidence. It is traditionally considered that key persons responsible for shaping witnesses' evidence are a prosecutor and a barrister. Very little attention has been paid so far to the influence of judicial remarks on the picture of the secondary reality resulting from courtroom examination. However, the data analysis demonstrates that judges, especially sitting alone, do shape the secondary reality, in many situations - through meta-utterances or smaller metapragmatic units.

Management of evidence by the judge is performed, first of all, through topic management. In example (13) the judge provides an explicit comment on his speech action (ask you to do), which predetermines the following speech behaviour of the claimant:

(13) Judge: What I will ask you to do though is this. If you either dispute that you ever made the concessions that the Defendants say you made, or you want now to reconsider... (Ir.)

In English judicial speech, metapragmatic topic management and intervention in examination often take the polite form of a question:

(14) JUDGE: Mr Irving, before you say what you want to say and before Mr Rampton starts, can I just say this. (Ir.).

Apparently, the judge is not supposed to ask for permission to interrupt, and the metapragmatic framing in example (14) actually serves to attract and hold attention on a particular topic.

The necessity to define a thematic circle of examination arises when a witness (or any other non-professional participant) feels unsure because the sphere of issues covered by the examination is rather wide. In the following example the judge enumerates paramount topics needed to be covered by the witness, as they form the prosecution case:

(15) Судья: ...Вот вы были Свидетелем Иеговы. И нам расскажите, на сегодня ставится вопрос о ликвидации этой общины, в связи с тем, первое, что они понуждают, разжсиают религиозную рознь, что они разрушают семью, что они склоняют к самоубийству и т.д. Вот на эти вопросы нам и отвечайте. (С.И.) [Judge: You were a Jehovah's witness. Now tell us, at present there has been raised an issue about the prohibition of the congregation because, firstly, they force, incite religious conflicts, they destroy families, they motivate suicides, etc. You should answer these particular questions. (J.W.)]

Judges do not only initiate discussions around particular topics; they also exert pressure on trial participants and force them back to certain topics which were not dealt with properly according to judicial discretion. The example from an English trial illustrates the situation when the judge compels the witness to return to an earlier suggestion made by the defendant:

(16) Judge: Whilst I am asking you questions, I am not sure you have really responded to the suggestion that was implicitly being put to you by Mr Irving which is that these objects that one can see on the roof of the gas chamber, alleged gas chamber, 
are, in fact, drums containing some sort of sealant. You have not actually dealt with that suggestion.

Witness: No, and I would like to deal with that, if it is possible? (Ir.)

In a Russian trial, when a witness avoids direct answers, the judge exercises her power and - with a metapragmatic utterance - makes him reconsider the topic:

(17) Судья: Вы опять уходите. Изолящия от общества. Расскажите, пожалуйста. (С.И.)

[Judge: You are leaving (changing the subject) again. Isolation from society. Tell us, please. (J.W.)]

In two languages the same communicative function is shaped differently in terms of linguistic forms. When urging the witness to revisit the topic, the English judge resorts to a declarative (You have not actually dealt with that suggestion) which is an indirect speech act. It is notable that the witness deciphers the judge's communicative intention correctly and chooses to follow the judicial instruction (I would like to deal with that). The Russian judge sounds more direct since she employs a direct imperative (расскажите - tell us).

Managing the quantity and quality of evidence is another function realised by judicial metapragmatic units. Controlling the quantity of evidence can take opposite forms: inducing discourse production and limiting it.

Carrying out the task of extracting complete information from witnesses, judges practise their power to prompt speakers to concentrate on specific issues and produce longer utterances:

(18) JUDGE: On the other hand, it is matter for you because I am letting you say pretty much what you want to say... (Ir.);

(19) JUDGE: Let us concentrate on this one (Ir.).

On the other hand, managing the quantity of evidence often takes the form of time control, when the judge gives short signals of understanding to speed up the examination and make it more dynamic: Поняла. Дальше, пожалуйста (I see. Continue, please), Дальие (Continuе), Достаточно (Enough).

In example (20) the judge reproaches the witness for using formulations that are not economical enough:

(20) Свидетель: ...Они расхваливают себя в нравственном смысле, это не христианская черта.

Судья: Хвалят себя. Все, поняла. Вы так много говорите, а в результате можно было сказать одним словом. (С.И.)

[Witness: ...They are praising themselves in terms of morality, but it is not a Christian feature.

Judge: Praising themselves. That's all, I see. You are saying so much, but you could cover everything with one word as a result. (J.W.)]

When discussing an issue, the English judge restricts a witness and refers to the fact that some information can be drawn from the written report:

(21) Judge: I just want to get the full picture. I do not want you to spend very long on this, but you deal with this in your report, do you not, at some length?

Witness: In detail, yes. (Ir.) 
With respect to judicial control of time, the question arises whether it may limit witnesses' freedom and cause gaps or misrepresentations in the reconstruction of the secondary reality. It seems, this danger is partly offset by judicial attention to the quality of evidence. Management of courtroom discourse quality is performed through judicial metapragmatic comments, one group of which is intended to control relevance. All irrelevant information is dismissed, and judges express their explicit demand to observe the relevance principle:

(22) Судья: Многим наркоманам помогли?

Свидетель: Ну, как сказать, порядка там 20 человек, которые достаточно долго употребляли достаточно разные наркотики и тяжелье наркотики.

Судья: Хорошо, это к нам не имеет отношения. (С.И.)

[Judge: Have you helped many drug addicts?

Witness: Well, what can I say, around 20 people who had been using for quite a long time rather different drugs and heavy drugs.

Judge: All right, it has nothing to do with the case. (H.N.)]

In examples (23) and (24) the claimant's evidence is evaluated by the judge in terms of relevance, and explicit metapragmatic markers (relevant; relevance) clarify the communicative intention of the judge:

(23) Judge: Is that not relevant only to costs? Tell me if I am wrong, but that would be the way I would see it. (Ir.);

(24) Judge: I do not see the relevance of telling me that unless and until it comes to the question of costs. (Ir.)

Another demand that judges put forward to shape evidence and — through it the secondary reality is the demand for precise and clearly presented factual information. Provided the judge receives accurate and exact information, the chance is slim that the picture of the secondary reality is distorted. Linguistically, this demand tends to take the interrogative form in English and imperative form in Russian. Remarks in both languages may contain specific lexical markers which manifest the judge's intention to clarify information have (not) understood, to elaborate, конкретно (exactly), уточнuм (make it clear):

(25) Judge: Yes, make your point on this because I have not understood it yet. (Ir.)

(26) Judge: Professor van Pelt, can I just make sure I have understood it, that when you say that these show the projections, whatever they may have been, you are talking about — can you see — that smudge there, that smudge there, that smudge there? (Ir.)

(27) Barrister: No, I'm sorry, that is one error that cannot be allowed to pass. There is a fourth leg, forensic chemical analysis both in 1945, 1988 and 1994. Judge: Just to elaborate that, of Leichenkeller I at crematorium II? (Ir.)

(28) Судья: Скажите конкретно, Вы знаете, к чему это привело? (С.И.) [Judge: Tell us exactly, do you know what it lead to? (J.W.)]

(29) Давайте уточним. Вы машину продали без двери? (Р.3.) [Let us make it clear. Did you sell the car without the door? (H.N.)]

It is notable that in example (25) the judge claims personal responsibility for the lack of understanding. This kind of judicial behaviour is typical of English judges only 
and can be viewed as a remedial action, which mitigates interruption and imposition of the judge's will on a witness.

Another function of metapragmatic units in judicial speech consists in pushing the witness towards deductions and conclusions based on evidence. The judge may ask different questions prompting the witness to logically finish his evidence. The judge addresses the expert witness with the following question:

(30) Judge: What have you found on that wall? What are the options? (H.N.)

(31) Судья: В «Сторожевой башне» написано 40 тысяч. У бывшего руководителя 67 тысяч. Вы говорите, что в эту иифру входят... Да, есть же те, которые действительно выведены из общества вот за те вещи, которые вы перечисляли, правильно? Но есть те, которые вылли по своему желанию, ну и что из это20? (С.И.)

[Judge: In Watch Tower it is written 40 thousand. The former leader writes 67 thousand. You say, this figure includes... Yes, there are those who were excluded for the reasons that you have enumerated, right? But there are those who left in accord with their own wish. So what? (J.W.)]

These questions do not automatically presuppose satisfactory answers to them unless they are answers of an expert, whose responsibility includes giving professional conclusions based on facts.

Generalising and summarising can be accomplished not only by witnesses but also by judges, who sum up facts and draw preliminary conclusions in the course of the hearing. In the following example the metapragmatic unit anyway is used by the judge to mark the end of the discussion and the beginning of the summary:

(32) Judge: Anyway, your position is you do not deny its authenticity, but you do say that the provenance is unsatisfactory. (Ir.)

Construction of the secondary reality in courts involves an array of metapragmatic resources with various functions in judicial speech. The analysis demonstrates that management of evidence is performed not only by the parties in the litigation but also by judges.

\subsection{Framing the law}

The third group of metapragmatic units and utterances is directed at framing juridical aspects of the trial. These metapragmatic units contribute to the identity of the judge as a representative of judicial power, who does not only own the legal right to rule the trial but also has knowledge of law that is absolutely necessary to manage the trial.

The necessity for comments on law arises before the judge when a witness is about to violate legal principles or rules. In the following example the judge explains to the witness the basic principles of the trial when the latter is going to use written materials when giving evidence:

(33) Свидетель: Ну, во-первых, я хотел бы сказать, что...

Судья: Что это перед вами?

Свидетель: Это мои материаль, которые я хотел бы, к которым я хотел бы обрашиаться. 
Судья: Нет, уважаемый, вы ведь свидетель. Я вам делаю замечание в этом плане. Вы можете смотреть, если даты какие-то, если циифры какие-то, пожалуйста.

Свидетель: Цитаты можно?

Судья: Ну, иитаты, если есть такая необходимость, конечно, естественно. А так вы непосредственно все говорите...

Свидетель: Все, хорошо. Я просто не знал.

Судья: ... все свои показания, устно, непосредственно - это принщип судебного nроиесса. (С.И.)

[Witness: Well, first of all, I would like to say that...

Judge: What is that in front of you?

Witness: These are my materials which I would like, to which I would like to refer. Judge: No, dear (respected), you are a witness. I give you a warning in this respect. You may check to see if there are any dates, or figures, please.

Witness: Are quotations allowed?

Judge: Well, quotations, if there is necessity, are allowed, of course. Otherwise, you speak spontaneously...

Witness: All right. I just didn't know.

Judge: ...All your evidence, orally, spontaneously - this is the principle of the trial. (J.W.)]

In fact, the judge quotes the text of the Procedural Code, which establishes the basic principles of the trial. The trial should be spontaneous, oral and continuous.

Trial participants are supposed to understand many aspects of current and past events in terms of law. However, non-professional participants are not always ready to perceive the reality from the legal perspective, and the judge turns out to play the role of a guide who explains legal concepts to witnesses and, through this, gives them points of reference.

In example (34) after the prosecutor's question whether the victim evaluated the damages as considerable, the judge interrupts to explain what is meant by considerable damages:

(34) Судья: Я Вам объясню, что это категория оценочная. То есть Вы были поставлены в затруднительное положение, Вам нечего было есть, негде было спать. (P.3.)

[Judge: I will explain to you that it is an assessment category. It means you were put into a predicament; you had nothing to eat, nowhere to sleep. (H.N.)]

It is notable that the legal category is explained in everyday terms, i.e. it is deciphered and made comprehensible for the non-professional. In a similar way, the judge expands on the meaning of the question about loan responsibilities:

(35) Судья: Долговые обязательства повлияют на Ваши показания? Правду будете нам говорить или соврете? (Р.3.)

[Judge: Will loan responsibilities influence your evidence? Will you tell us the truth or lies? (H.N.)]

In these metapragmatic instances of courtroom speech, a transformation occurs that can be presented as «legal category $\rightarrow$ everyday concepts». This transformation is 
brought about by the judge so that the witness can appropriately evaluate the events in terms of legal reality.

The direction of the transformation may be opposite. In this case the events of real life get interpreted through legal categories and qualifications: «everyday concepts $\rightarrow$ legal category». For instance, the judge qualifies in legal terms the actions of the witness who bought a stolen car door from the criminals:

(36) Судья: Это называется подстрекательство к совершению преступления. Да, Храмкин? (апеллячия к подсудимому - Т.Д.) Это причина, способствуюшая совершению преступления. Если бы Вы не согласились купить дверь, он бы не совершил преступление и не сидел на скамье подсудимых. (Р.3.)

[Judge: It is called incitement to committing a crime. Right, Khramkin? (an appeal to the defendant - T.D.) This is a reason conducive to a crime commitment. If you had not agreed to buy the door, he would not have committed the crime and would not be sitting in the dock. (H.N.)]

In the following short dialogue, the judge unambiguously informs the victim of the rule of law and the impossibility to ignore it in legal environment. The victim reported a theft to the police but later on he wants to withdraw the application:

(37) Потерпевший: Я хотел забрать (заявление - Т.Д.).

Судья: Здесь такого не может быть. Дал, забрал... (Р.3.)

[Victim: I wanted to withdraw (the application - T.D.).

Judge: It cannot be like this here. Reporting and then withdrawing... (H.N.)]

The adverb здесь (here) signifies 'the territory of law', where trial participants can only accept rules and regulations. They are not allowed to comment on law or perform duties of professional participants. When a witness tries to comment on the legal reality it causes the judge's discontent followed by an interruption:

(38) Судья: ...Вот, вовлечение несовершеннолетних. Что вы имеете в виду?

Свидетель: Вовлечение тех людей, которые не достигли 18 лет.

Судья: Я поняла. Что вы имеете в виду? Я поняла, кому нет 18 лет - это суду объяснять не надо. Что вы под этим имеете в виду?

Свидетель: Ну то, что как бы проповедуется тем лицам, которые... то есть, вовлекаются лица в организацию, которые... не достигли совершеннолетия. (С.И.)

[Judge: ...So, involving underage people. What do you mean?

Witness: Involving people who haven't reached the age of 18.

Judge: I have understood. What do you mean? I know, who hasn't reached the age of 18. You don't have to explain this to the court. What do you mean by this?

Witness: Well, that somehow it is preached to people who...that is, people are involved in the organisation who haven't come of age. (H.N.)]

As can be seen in the example, the witness misinterprets the judge's question. Instead of considering factual information, he turns to the meaning of the legal concept 'an underage person', which is not only excessive but also destructive to the usual distribution of functions in the courtroom. The role of the mediator between the legal reality and the primary reality of the courtroom belongs to a judge, not a witness, and it is made manifest through the metapragmatic comment of the judge. 
Professional participants are more aware of the distribution of roles in court and leave the right of interpreting law to the judge. The following excerpt presents the situation in which the claimant, who is conducting the examination, does not take the responsibility of explaining the concept of 'burden of proof' to the witness and refers the witness to the judge. The judge provides a detailed instruction on how the case should be dealt with and what procedure applies:

(39) Claimant: Professor van Pelt, I think that his Lordship will educate you as to the burden of proof in an English defamation action.

Judge: I am not sure that is really quite right. If you are not saying that these are fakes, and I think you just told me that you were not putting forward that positive case, then it does not seem to me that it is necessary for this witness to refer to the expert analysis at all. But, if you are saying it is a forgery or has been tampered with in some way, then it may be that we do need to see what the expert said. (Ir.)

Moreover, judges practise their power in court by allowing trial participants to perform actions which may seem not in accordance with the official procedure. In the following fragment the metapragmatic remark of the judge is based on his personal subjective opinion on the appropriateness of speech actions that the claimant is going to perform:

(40) Claimant: ...That is the kind of material that I would have put to them.

Judge: Well, I am not sure that is actually right, as a matter of law, but I am taking a liberal approach. Say what you have indicated you intend to say in due course. (Ir.)

Exercising judicial discretion appears to be part of justice administration as well as construction of judicial identity.

\section{CONCLUSION}

Metapragmatic comments constitute an essential part of judicial discourse. These comments contribute to constructing the primary reality, i.e. the reality of the courtroom, the secondary reality, i.e. the reality of a misdemeanor or a crime, and the reality of law. Based on this, metapragmatic utterances can be grouped in three types. Their general function being regulative, judicial metapragmatic units perform a number of more specific functions which allow the judge to organize a trial in a consistent way, to exercise judicial power and discretion and — through these — to construct the judicial identity and administer justice.

Functional specifics of judicial metapragmatic utterances are predetermined by legal and procedural norms as well as legal culture of participants. Lack of courtroom experience leads to procedural and behavioural violations, that are corrected by judicial metapragmatic remarks.

From a formal perspective, metapragmatics involves a wide array of linguistic means - from separate lexical units and introductory constructions to complete utterances consisting of a few sentences.

Russian and English judicial metapragmatic remarks reveal differences in their linguistic realizations. While English judges tend to mitigate instructions and resort to 
indirect speech acts (declaratives and interrogatives) to perform judicial control, Russian judges are more direct and exploit imperatives and modal verbs. This leads to the conclusion that linguistic realization of metapragmatics is to some degree predetermined by national specifics of other communicative categories, e.g. politeness category.

The metapragmatic component of judicial discourse should not be viewed as a mere supplement to the factual content, as it plays a principal role in sustaining court as a social institution, constructing judge's identity as a figure of power and, as a result, administering justice.

(C) Tatiana Dubrovskaya, 2017

\section{REFERENCES}

Andrus, Jeniffer (2009). The development of artefactual language ideology: utterance, event, and agency in the metadiscourse of the excited utterance exception to hearsay. Language and Communication, 29, 312-327.

Caffi, Claudia (2006). Metapragmatics. In Keith Brown (ed.), Encyclopedia of Language and Linguistics. Amsterdam: Elsevier, 82-88.

Carranza, Isolda E. (2008). Metapragmatics in a courtroom genre. Pragmatics, 18:2, 169-188.

Ciliberti, Anna \& Laurie Anderson (2007). Metapragmatics comments in institutional talk: a comparative analysis across settings. In Wolfram Bublitz, Alex Hübler (eds.) Metapragmatics in Use. Amsterdam: John Benjamins, 143-166.

Fuertes-Olivera, Pedro A., Marisol Velasco-Sacristán, Ascensión Arribas-Baño \& Eva SamaniegoFernández (2001). Persuasion and advertising English: metadiscourse in slogans and headlines. Journal of Pragmatics, 33 (8), 1291-1307.

Gibbons, John (2003). Forensic Linguistic. An Introduction to Language in the Justice System. Oxford: Blackwell Publishing.

Gillaerts, Paul \& Freek Van de Velde (2010). Interactional metadiscourse in research article abstracts. Journal of English for Academic Purposes, 9, 128-139.

Haberland, Hartmut (2007). Language shift in conversation as metapragmatic comment. In Wolfram Bublitz, Alex Hübler (eds.) Metapragmatics in Use. Amsterdam: John Benjamins, 129—140.

Hübler, Alex \& Wolfram Bublitz (2007). Introducing metapragmatics in use. In Wolfram Bublitz, Alex Hübler (eds.) Metapragmatics in Use. Amsterdam: John Benjamins, 1-26.

Hyland, Ken (2004). Disciplinary interactions: metadiscourse in L2 postgraduate writing. Journal of Second Language Writing, 13, 133-151.

Hyland Ken (1998). Persuasion and context: the pragmatics of academic metadiscourse. Journal of Pragmatics, 30 (4), 437-455.

Hyland, Ken \& Polly Tse (2004). Metadiscourse in academic writing: a reappraisal. Applied Linguistics, 25, 156-177.

Ifantidou, Elly (2005). The semantics and pragmatics of metadiscourse. Journal of Pragmatics, 37 , $1325-1353$.

Ilie, Cornelia (2003). Discourse and metadiscourse in parliamentary debates. Journal of Language and Politics, 2:1, 71-92.

Janney, Richard W. (2007). "So your story now is that...": metapragmatic framing strategies in courtroom interrogation. In Wolfram Bublitz, Alex Hübler (eds.) Metapragmatics in Use. Amsterdam: John Benjamins, 223-235. 
Khabbazi-Oskouei, Leile (2013). Propositional or non-propositional, that is the question: a new approach analyzing 'interpersonal metadiscourse' in editorials. Journal of Pragmatics, 47, 93-107.

Mur-Dueñas, Pilar (2011). An intercultural analysis of metadiscourse features in research articles written in English and in Spanish. Journal of Pragmatics, 43, 3068-3079.

Mur-Dueñas, Pilar (2007). “I/we focus on...”: a cross-cultural analysis of self-mentions in business management research articles. Journal of English for Academic Purposes, 6, 143-162.

Penz, Hermine (2007). Building common ground through metapragmatic comments in international project work. In Wolfram Bublitz, Alex Hübler (eds.) Metapragmatics in Use. Amsterdam: John Benjamins, 263-292.

Philips, Susan U. (1998). Ideology in the Language of Judges. How Judges Practice Law, Politics and Courtroom Control. New York, Oxford: Oxford University Press.

Schubert, Christoph (2012). Follow-up questions in White House press briefings: metacommunication in cohesion and framing. Language and Dialogue, 2:3, 449-463.

Stubbs, Michael (1983). Discourse Analysis: The Sociolinguistic Analysis of Natural Language. Oxford: Blackwell Publishing.

Suzuki, Satoko (2007). Metapragmatic function of quotative markers in Japanese. In Wolfram Bublitz, Alex Hübler (eds.) Metapragmatics in Use. Amsterdam: John Benjamins, 73-85.

Thompson, Susan Elizabeth (2003). Text-structuring metadiscourse, intonation and the signalling of organization in academic lectures. Journal of English for Academic Purposes, 2, 5-20.

Vande Kopple, William J. (2012). The importance of studying metadiscourse. Applied Research in English, 1(2), 37-44.

Викторова Е. Ю. Лингвокультурное своеобразие вспомогательных коммуникативных единиц в политическом дискурсе (на материале русского и английского языков). Известия ВУЗов. Поволжский регион. Гуманитарные науки, 2011. № 3, 91—97. [Viktorova, E. Yu. (2011). Lingvokul'turnoe svoeobrazie vspomogatel'nykh kommunikativnykh edinits v politicheskom diskurse (na materiale russkogo i angliiskogo yazykov) Linguocultural specifics of supplementary communicative units in political discourse (based on Russian and English languages). University Proceedings. The Volga Region. Humanities, 3, 91-97.

\section{Data}

1. Ir. - Trial transcripts of 'David John Cawdell Irving (claimant) and Penguin Books Limited, Deborah E. Lipstadt (defendants)' (2000). URL: http://www.fpp.co.uk.

2. Sh. - Trial transcripts of Shipman 'Regina v. Harold Shipman' (2001). URL: http://webarchive.nationalarchives.gov.uk/20090808154959/http://www.the-shipmaninquiry.org.uk/reports.asp.

3. J.W. - Transcripts of the trial against the Jehovah's Witnesses Organisation (1998-2002). URL: http://www.jw-media.org/region/europe/russia/russian/moscow/u_courttranscripts.htm.

4. H.N. - Handwritten.

\section{Article history:}

Received: 01 July 2016

Revised: 10 October 2016

Accepted: 01 November 2016

\section{For citation:}

Dubrovskaya, T. (2017). Metapragmatics of Administering Justice in Russian and English Judicial Discourse. Russian Journal of Linguistics, 21 (1), 73-90. 


\title{
Bio Note:
}

Tatiana Dubrovskaya, Dr, Associate Professor, Chair of English Language Department at Penza State University. Research Interests: Discourse Analasis, Judicial discourse, Political Linguistics, Pragmatics, Speech Genres, Language and Culture, Theory of Politeness. Contact information: e-mail: gynergy74@gmail.com

\section{МЕТАПРАГМАТИКА ОСУЩЕСТВЛЕНИЯ ПРАВОСУДИЯ В ДИСКУРСЕ РОССИЙСКИХ И АНГЛИЙСКИХ СУДЕЙ}

\author{
Т.В. Дубровская \\ Пензенский государственный университет \\ 44000, Пенза, Россия, ул. Красная, д. 40
}

Настоящая статья делает вклад в исследование метапрагматики в условиях судебной коммуникации, в частности в дискурсе русских и английских судей, и представляет результаты функционального анализа метапрагматических элементов. В статье утверждается, что метавысказывания являются свойством судейского дискурса, в котором они выполняют особые функции, связанные с реализацией власти и судейского усмотрения, а также с осуществлением правосудия. Обсуждаются функции метавысказываний, выделяемые в научной литературе, и предлагается классификация метапрагматических элементов в судейском дискурсе в соответствии с тремя типами реальности, выделяемыми Дж. Гиббонсом (Gibbons 2003). Первая группа метапрагматических элементов способствует созданию первичной реальности, т.е. реальности судебного заседания; вторая группа помогает формировать вторичную реальность, т.е. реальность преступления или правонарушения; третья группа конструирует реальность права. Взятые вместе, все типы метапрагматических элементов создают организующую рамку судебного процесса. Речевые данные для анализа включают стенограммы современных судебных заседаний (1998-2008). Применение русских и английских данных позволяет продемонстрировать, что основные функции метавысказываний в судейском дискурсе обнаруживают значительный параллелизм, в то время как незначительные различия связаны с другими прагматическими категориями, в которых проявляется национально-культурная специфика коммуникации, например, с вежливостью.

Ключевые слова: метапрагматика, судейский дискурс, функция, зал суда, русский, английский

\section{История статьи:}

Дата поступления в редакцию: 01 июля 2016

Дата принятия к печати: 01 ноября 2016

\section{Для цитирования:}

Дубровская Т.В. Метапрагматика осуществления правосудия в дискурсе российских и английских судей // Вестник Российского университета дружбы народов. Серия: Лингвистика. 2017. Т. 21. № 1. С. $73-90$.

\section{Сведения об авторах:}

Дубровская Татьяна Викторовна, доктор филологических наук, доцент, заведующая кафедрой английского языка Пензенского государственного университета. Сфера научных интересов: дискурсивный анализ, судебный дискурс, политическая лингвистика, лингвистическая прагматика, речевые жанры, теория вежливости. Контактная информация: e-mail: gynergy74@gmail.com 